\title{
Front Matter: Volume 10976
}

, "Front Matter: Volume 10976," Proc. SPIE 10976, 21st Czech-Polish-Slovak Optical Conference on Wave and Quantum Aspects of Contemporary Optics, 1097601 (18 December 2018); doi: 10.1117/12.2523687

SPIE Event: 21st Czech-Polish-Slovak Optical Conference on Wave and Quantum SPIE. Aspects of Contemporary Optics, 2018, Lednice, Czech Republic 


\title{
21 st Czech-Polish-Slovak Optical Conference on Wave and Quantum Aspects of Contemporary Optics
}

\author{
Pavel Zemánek \\ Editor
}

\section{3-7 September 2018}

Lednice, Czech Republic

Organized by

Institute of Scientific Instruments of the CAS, v. v. i. (Czech Republic)

Sponsored by

Olympus Czech Group, s.r.o. (Czech Republic)

OptiXs, s.r.o. (Czech Republic)

Photon Systems Instruments, spol. s.r.o. (Czech Republic)

Meopta - optika, s.r.o. (Czech Republic)

Published by

SPIE 
The papers in this volume were part of the technical conference cited on the cover and title page. Papers were selected and subject to review by the editors and conference program committee. Some conference presentations may not be available for publication. Additional papers and presentation recordings may be available online in the SPIE Digital Library at SPIEDigitalLibrary.org.

The papers reflect the work and thoughts of the authors and are published herein as submitted. The publisher is not responsible for the validity of the information or for any outcomes resulting from reliance thereon.

Please use the following format to cite material from these proceedings:

Author(s), "Title of Paper," in 21 st Czech-Polish-Slovak Optical Conference on Wave and Quantum Aspects of Contemporary Optics, edited by Pavel Zemánek, Proceedings of SPIE Vol. 10976 (SPIE, Bellingham, WA, 2018) Seven-digit Article CID Number.

ISSN: 0277-786X

ISSN: 1996-756X (electronic)

ISBN: 9781510626072

ISBN: 9781510626089 (electronic)

Published by

SPIE

P.O. Box 10, Bellingham, Washington 98227-0010 USA

Telephone +1 3606763290 (Pacific Time) · Fax +1 3606471445

SPIE.org

Copyright (C) 2018, Society of Photo-Optical Instrumentation Engineers.

Copying of material in this book for internal or personal use, or for the internal or personal use of specific clients, beyond the fair use provisions granted by the U.S. Copyright Law is authorized by SPIE subject to payment of copying fees. The Transactional Reporting Service base fee for this volume is $\$ 18.00$ per article (or portion thereof), which should be paid directly to the Copyright Clearance Center (CCC), 222 Rosewood Drive, Danvers, MA 01923. Payment may also be made electronically through CCC Online at copyright.com. Other copying for republication, resale, advertising or promotion, or any form of systematic or multiple reproduction of any material in this book is prohibited except with permission in writing from the publisher. The CCC fee code is 0277$786 \mathrm{X} / 18 / \$ 18.00$.

Printed in the United States of America.

Publication of record for individual papers is online in the SPIE Digital Library.

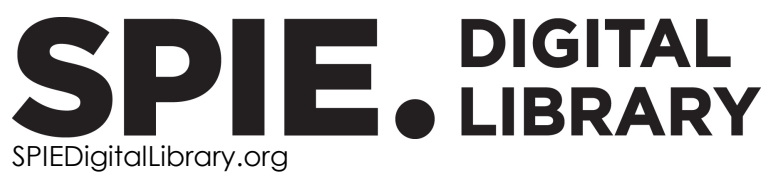

Paper Numbering: Proceedings of SPIE follow an e-First publication model. A unique citation identifier (CID) number is assigned to each article at the time of publication. Utilization of CIDs allows articles to be fully citable as soon as they are published online, and connects the same identifier to all online and print versions of the publication. SPIE uses a seven-digit CID article numbering system structured as follows:

- The first five digits correspond to the SPIE volume number.

- The last two digits indicate publication order within the volume using a Base 36 numbering system employing both numerals and letters. These two-number sets start with $00,01,02,03,04$, 05, 06, 07, 08, 09, 0A, OB ... 0Z, followed by 10-1Z, 20-2Z, etc. The CID Number appears on each page of the manuscript. 


\title{
Contents
}

\author{
vii $\quad$ Authors \\ ix Conference Committee \\ xiii Introduction
}

IMAGING AND BIOPHOTONICS I

1097602 Optical vortex scanning microscope: simple phase recovery [10976-22]

METROLOGY AND SENSORS I

1097603 An optical magnetometer based on the magneto-optical Kerr effect [10976-43]

1097604 Optical fibers forming to ionizing radiation sensors preparation [10976-14]

1097605 Investigating the use of the hydrogen cyanide (HCN) as an absorption media for laser spectroscopy [10976-8]

\section{METROLOGY AND SENSORS II}

1097606 Surface plasmon resonance for air used for characterization of a metallic layer [10976-15]

1097607 Measurement system for characterization of angular and spectral distribution of LED-based sources [10976-28]

1097608 Linearized and compensated interferometric system for high-velocity traceable length calibration on a metre scale [10976-45]

\section{METROLOGY AND SENSORS III}

1097609 Analysis of fringe patterns with variable density using modified variational image decomposition aided by the Hilbert Transform [10976-11]

10976 OA Optical activity temperature-dependent measurements of chiral solutions using Mueller matrix spectroscopic ellipsometry [10976-46] 
METROLOGY AND SENSORS IV

10976 OB A method of chromatic dispersion retrieval from a zero-mean spectral interferogram [10976-44]

MICROPHOTONICS AND MICROFABRICATION I

10976 OC Double wavelength multifunctional optical tweezers (Invited Paper) [10976-30]

10976 OD Tool fabrication for automated indirect optical micro-manipulation [10976-5]

10976 OE Anomalous shift of the most probable position of a particle in an unstable optically created potential [10976-17]

MICROPHOTONICS AND MICROFABRICATION II

10976 OF 3D polymer-based woodpile structure for application in photonics (Invited Paper) [10976-25]

10976 OG Motion of optically levitated nanoparticle in nonlinear regime [10976-16]

WAVE AND GEOMETRICAL OPTICS I

$10976 \mathrm{OH} \quad$ Dynamic gratings induced by mode instabilities in fiber lasers (Invited Paper) [10976-2]

10976 Ol Microstructure and optical properties of black silicon layers [10976-32]

10976 0J Polarizing fibre facet gratings with high modal reflectance [10976-6]

WAVE AND GEOMETRICAL OPTICS II

10976 OK Optical systems for laser-produced plasma EUV and soft $x$-ray sources [10976-20]

ADVANCED FIBER TECHNOLOGIES I

10976 OL Watt-level broadband mid-infrared supercontinuum generation in selected soft-glass fibers: recent works at MUT [10976-3]

iv 
POSTER SESSION: METROLOGY AND SENSORS

10976 OM Laser system for measuring MEMS relief created by the method of deep reactive ion etching [10976-13]

10976 ON Optical fiber-based ionizing sensors preparation [10976-36]

1097600 White-light interferometry without depth scan [10976-9]

10976 OP Sensing of liquid analytes using surface plasmon resonance at different angles of incidence [10976-10]

10976 OQ Optical amplification for quantum sources of ultra-stable optical frequency [10976-1]

\section{POSTER SESSION: DESIGN AND MANUFACTURE OF OPTICAL COMPONENTS}

10976 OR Polymer-based Mach-Zehnder interferometer for on-chip applications [10976-34]

10976 OS Optical microring structure applied at the end of the optical fiber [10976-29]

10976 OT 3D polymer-based air-bridge waveguides for on chip applications [10976-19]

10976 OU Design and preparation of polymer-based microspectrometer using laser lithography [10976-26]

10976 OV Polymer-based 3D microcones for application in SERS [10976-41]

10976 OW Polymer photonic structures for lab-on-a-fiber applications [10976-18]

10976 OX Modification of angular photoresponse of InGaAsN-based photodiode with 3D woodpile structures [10976-27]

10976 OY Woodpile structure: effective diffractive photonic element [10976-7]

$109760 Z$ Numerical investigation of critical fiber optic high-speed transmission system properties [10976-42]

POSTER SESSION: QUANTUM OPTICS

$1097610 \quad$ Modeling of optical burst switching networks [10976-37]

$1097611 \quad$ Kerr-type nonlinear quantum oscillator: quantum correlations, chaotic, and regular dynamics [10976-4] 
$1097612 \quad$ Einstein-Podolsky-Rosen steering and squeezing effect in system two coupled nonlinear oscillators [10976-24]

POSTER SESSION: WAVE AND GEOMETRICAL OPTICS

1097613 On correction of the resonant condition in the effect of surface plasmon resonance [10976-39]

$1097614 \quad$ Analytical model of Gouy phase influence in terahertz time-domain spectroscopy [10976-38]

1097615 Tolerance analysis of coherent combining optical system [10976-21]

1097616 Birefringence of pure and doped lithium niobate crystals [10976-23]

POSTER SESSION: ADVANCED FIBER TECHNOLOGIES

1097617 Optical frequency transfers between ISI CAS and CESNET [10976-40]

POSTER SESSION: IMAGING AND BIOPHOTONICS

$1097618 \quad$ Laser tweezers Raman spectroscopy of $E$. coli under antibiotic stress in microfluidic chips [10976-12]

1097619 Surface-enhanced Raman spectroscopy of chloroalkanes in microfluidic chips [10976-33]

10976 1A Comparison of contrast sensitivity tests for two types of targets: Gabor patches and modulated by Bessel profiles [10976-31] 


\section{Authors}

Numbers in the index correspond to the last two digits of the seven-digit citation identifier (CID) article numbering system used in Proceedings of SPIE. The first five digits reflect the volume number. Base 36 numbering is employed for the last two digits and indicates the order of articles within the volume. Numbers start with 00, 01, 02, 03, 04, 05, 06, 07, 08, 09, 0A, 0B...0Z, followed by 10-12, 20-2Z, etc.

\author{
Altmann, Michal, $O Q$ \\ Altmannova, Lada, $0 Q$ \\ Aubrecht, Jan, $\mathrm{OH}$ \\ Bánó, Gregor, OD \\ Bartnik, A., OK \\ Bernatová, Silvie, 18 \\ Bezděková, l., 13 \\ Brzobohatý, Oto, OE, OG \\ Buryška, Tomáš, 19 \\ Cajzl, Jakub, $\mathrm{OH}$ \\ Chlebus, R., OP, 13 \\ Chylek, J., 06 \\ Číp, Ondřej, 05, 08, 0Q, 17 \\ Ciprian, D., 06, OP, 13 \\ Čížek, Martin, 05, 0Q, 17 \\ Cywińska, Maria, 09 \\ Damborský, Jiří, 19 \\ Damková, Jana, OG \\ Dawidowski, Wojciech, OX \\ Drabik, Dominik, OC \\ Drobczynski, Slawomir, OC \\ Drzik, M., 03 \\ Ďurišová, Jana, OR \\ Dus-Szachniewicz, Kamila, OC \\ Fiedorowicz, H., OK \\ Figurová, Mária, OR \\ Filip, Radim, OE, OG \\ Fok, T., OK \\ Gašo, Peter, OR, OS, OV \\ Gontar, Przemyslaw, 15 \\ Goraus, Matej, OF, OT, OV, OW, OX, OY \\ Havlis, Ondrej, OQ, 17 \\ Hazlinsky, Michal, $O Q$ \\ Herman, Ondrej, 08 \\ Hlubina, P., 06, OP, 13 \\ Holá, Michaela, OZ, 10 \\ Hola, Miroslava, 08 \\ Holubec, Viktor, OE \\ Honzátko, Pavel, $\mathrm{OH}, \mathrm{OJ}$ \\ Horvath, Tomas, $\mathrm{OQ}$ \\ Hošek, Martin, 05 \\ Hrabina, Jan, 05, 0Q, 17 \\ Hucl, Vaclav, 0Q, 17 \\ llit, T., 03 \\ Imamura, Kentaro, OI \\ Jabczynski, Jan K., 15 \\ Jákl, Petr, 07, OE, OG \\ Jandura, Daniel, OS, OU, OV \\ Jarosik, M. W., 11
}

Jedlicka, Petr, 08

Jelinek, Michal, 04, 08, 0N, 17

Ježek, Jan, 07, 18, 19

Jurečka, Stanislav, 01

Káčik, Daniel, 0W, 16

Kalaga, J. K., 11, 12

Kaňok, R., OP

Kašík, Ivan, $\mathrm{OH}$

Kirchhoff, Johanna, 18

Kizovský, Martin, 19

Kobayashi, Hikaru, 01

Koleják, P., 14

Korzeniewska, Aleksandra, OC

Kovac, Jaroslav, Jr., OV

Kowalewska-Kudłaszyk, A., 11, 12

Králik, Martin, 0 I

Krátký, Stanislav, OM, 19

Kubacková, Jana, OD

Kundrat, Jan, $0 Q$

Kuzma, Anton, OR

Ladányi, Libor, 0Z, 10

Lamperska, Weronika, 02, 0C

Laurencikova, Agata, OV

Lazar, Josef, 08, 17

Leoński, W., 11, 12

Lettrichova, Ivana, OV

Maňka, Tadeáš, OM

Markotan, M., OU

Martincek, Ivan, OT, OW

Martynkien, Tadeusz, OB

Masajada, Jan, 02

Matej, Zdenek, 08

Matsumoto, Taketoshi, 0I

Maxova, V., 03

Mičica, Martin, OA, 14

Mikel, Bretislav, 04, 08, 0N, 17

Mikeska, Erik, 00

Müllerová, Jarmila, 0Z, 10

Munster, Petr, $0 Q$

Neugebauer, Ute, 18

Novak, Jozef, OV

Olszewski, Jacek, OB

Ornigotti, Luca, OE

Patorski, Krzysztof, 09

Patrzykont, M., 1A

Pavliček, Pavel, 00

Peřina, Jan, Jr., 12

Peterka, Pavel, $\mathrm{OH}$

Pilát, Zdeněk, 18, 19 
Pinčík, Emil, Ol

Pištora, Jaromír, OA, 14

Pniewski, J., $1 \mathrm{~A}$

Podrazký, Ondřej, $\mathrm{OH}$

Popiołek-Masajada, Agnieszka, 02

Postava, Kamil, OA, 14

Pravdová, Lenka, 05, 0Q, 17

Prokop, Zbyněk, 19

Pudiš, Dušan, OF, OR, OS, OT, OU, OV, OY

Radil, Jan, $O Q$

Řeřucha, Šimon, 05, 08, 0Q

Ryabov, Artem, $\mathrm{OE}$

Samek, Ota, 18, 19

Scholtz, Lubomir, 0Z, 10

Sciána, Beata, OX

Senderakova, D., 03

Šerý, Mojmír, 07, OM

Šiler, Martin, OE, OG, 19

Škereň, Marek, 07

Skoda, Pavel, $0 Q$

Slapak, Martin, $0 Q$

Smotlacha, Vladimir, 0Q, 17

Sobota, Jaroslav, 19

Suslik, Lubos, OX

Swiderski, J., OL

Szczęśniak, R., 11

Tannert, Astrid, 18

Tarjányi, Norbert, 16

Tłaczała, Marek, OX

Todorov, Filip, $\mathrm{OH}$

Tomori, Zoltan, OD

Trusiak, Maciej, 09

Urbancová, Petra, OF, OT, OX, OY

Urbanczyk, Waclaw, OB

Vala, Daniel, OA

Vaňáček, Pavel, 19

Vanek, Martin, OJ

Velc, Radek, $\mathrm{OQ}$

Vohnout, Rudolf, $O Q$

Vojtech, Josef, OQ, 17

Wachulak, P., OK

Wasylczyk, Piotr, OC

Węgrzyński, Ł., OK

Wosik, J., IA

Zemánek, Pavel, 07, 0E, 0G, 0M, 18, 19

Zolnacz, Kinga, OB 


\section{Conference Committee}

Conference Chair

Pavel Zemánek, Institute of Scientific Instruments of the CAS, v.v.i.

(Czech Republic)

Honorary Chairs

Jan Perina, Jr., Palacký University Olomouc (Czech Republic)

Dagmar Senderáková, Comenius University (Slovakia)

Tomasz Szoplik, University of Warsaw (Poland)

Organizing Committee

Eva Uhrová, Academic and Medical Conference Agency

(Czech Republic)

Rudolf Kinc, Academic and Medical Conference Agency

(Czech Republic)

Lenka Čermáková, Institute of Scientific Instruments of the CAS, v.v.i. (Czech Republic)

Pavla Schieblová, Institute of Scientific Instruments of the CAS, v.v.i. (Czech Republic)

Ondřej Číp, Institute of Scientific Instruments of the CAS, v.v.i.

(Czech Republic)

Bedrich Coufal, Institute of Scientific Instruments of the CAS, v.v.i.

(Czech Republic)

Scientific Committee

Jiři Čtyroký, Institute of Photonics and Electronics of the CAS, v.v.i.

(Czech Republic)

Jaromír Fiurášek, Palacký University Olomouc (Czech Republic)

Petr Hlubina, VŠB-Technical University of Ostrava (Czech Republic)

Jirí Homola, Institute of Photonics and Electronics of the CAS, v.v.i. (Czech Republic)

Pavel Honzátko, Institute of Photonics and Electronics of the CAS, v.v.i. (Czech Republic)

Miroslav Hrabovský, Joint Laboratory of Optics, Palacký University

Olomouc (Czech Republic) and Institute of Physics of the CAS, v.v.i. (Czech Republic)

Radim Chmelík, Brno University of Technology (Czech Republic)

Helena Jelínková, Czech Technical University in Prague

(Czech Republic) 
Josef Lazar, Institute of Scientific Instruments of the CAS, v.v.i.

(Czech Republic)

Vít Lédl, Institute of Plasma Physics of the CAS, v.v.i. (Czech Republic) Tomáš Mocek, Institute of Physics of the CAS, v.v.i. (Czech Republic) Jiř́ Novák, Czech Technical University in Prague (Czech Republic) Jan Perina, Jr., Joint Laboratory of Optics, Palacký University Olomouc (Czech Republic) and Institute of Physics of the CAS, v.v.i. (Czech Republic)

Jiří Petráček, Brno University of Technology (Czech Republic) Jaromír Pištora, VŠB-Technical University of Ostrava (Czech Republic) Ivan Richter, Czech Technical University in Prague (Czech Republic) Tomáš Šikola, Brno University of Technology (Czech Republic) Tomáš Tyc, Masaryk University (Czech Republic) Gregor Bánó, University of Pavel Josef Šafárik, Košice (Slovakia) Ivan Glesk, University of Strathclyde (United Kingdom) Dušan Chorvát, International Laser Center (Slovakia) Alžběta Marček Chorvátová, International Laser Center (Slovakia) Stanislav Jurečka, University of Žilina (Slovakia) Jaroslav Kováč, Slovak University of Technology (Slovakia) Jarmila Müllerová, University of Žilina (Slovakia) Dušan Pudiš, University of Žilina (Slovakia) Ján Turán, Technical University of Košice (Slovakia) František Uherek, International Laser Center (Slovakia) Konrad Banaszek, University of Warsaw (Poland) Ryszard Buczynski, University of Warsaw (Poland) Jan Jabczyński, Military University of Technology (Poland) Zbigniew Jaroszewicz, Institute of Applied Optics (Poland) Andrzej Kołodziejczyk, Warsaw University of Technology (Poland) Wieslaw Krolikowski, The Australian National University (Australia) Wieslaw Leoński, University of Zielona Góra (Poland) Jan Masajada, Wrocław University of Science and Technology (Poland) Adam Miranowicz, Adam Mickiewicz University (Poland) Wacław Urbanczyk, Wrocław University of Science and Technology (Poland)

Tomasz R. Woliński, Warsaw University of Technology (Poland)

Session Chairs

$1 \quad$ Imaging and Biophotonics I

Pavel Zemánek, Institute of Scientific Instruments of the CAS, v.v.i.

(Czech Republic)

2 Imaging and Biophotonics II

Radim Chmelík, Brno University of Technology (Czech Republic)

3 Metrology and Sensors I

Petr Hlubina, VŠB-Technical University of Ostrava (Czech Republic) 
4 Metrology and Sensors II

Jan Hrabina, Institute of Scientific Instruments of the CAS, v.v.i.

(Czech Republic)

5 Metrology and Sensors III

Ondřej Číp, Institute of Scientific Instruments of the CAS, v.v.i.

(Czech Republic)

6 Metrology and Sensors IV

Břetislav Mikel, Institute of Scientific Instruments of the CAS, v.v.i.

(Czech Republic)

$7 \quad$ Microphotonics and Microfabrication I

Dušan Pudiš, University of Žilina (Slovakia)

8 Microphotonics and Microfabrication II

Sławomir Drobczyński, Wrocław University of Science and Technology (Poland)

9 Presentation of Companies

Pavel Zemánek, Institute of Scientific Instruments of the CAS, v.v.i.

(Czech Republic

10 Wave and Geometrical Optics I

Jirí Čtyroký, Institute of Photonics and Electronics of the CAS, v.v.i.

(Czech Republic)

11 Wave and Geometrical Optics II

Wacław Urbanczyk, Wrocław University of Science and Technology

(Poland)

12 Advanced Fiber Technologies I

Ryszard Buczynski, University of Warsaw (Poland)

13 Advanced Fiber Technologies II

Ivan Richter, Czech Technical University in Prague (Czech Republic)

14 Quantum Optics I

Jan Peřina, Jr., Joint Laboratory of Optics, Palacký University Olomouc (Czech Republic) and Institute of Physics of the CAS, v.v.i.

(Czech Republic)

15 Quantum Optics II

Jan Soubusta, Joint Laboratory of Optics, Palacký University Olomouc and Institute of Physics of the CAS, v.v.i. (Czech Republic) 
Proc. of SPIE Vol. 10976 1097601-12 Downloaded From: https://www.spiedigitallibrary.org/conference-proceedings-of-spie on 25 Apr 2023
Terms of Use: https://www.spiedigitallibrary.org/terms-of-use 


\section{Introduction}

This conference is a continuation of a series of regular meetings of the Czech, Polish, and Slovak optical communities which started in Rusava (Czech Republic) in 1972. After a short interruption between 1980 and 1990, the meetings have grown, and are known as the "Wave and Quantum Aspects of Contemporary Optics." For 40 years, this conference has been organized biannually by turns in Slovakia, Czech Republic, and Poland, and has become a place to exchange knowledge on the latest optical research, and to meet friends and coworkers, as well as young scientists.

Pavel Zemánek 
Proc. of SPIE Vol. 10976 1097601-14

Downloaded From: https://www.spiedigitallibrary.org/conference-proceedings-of-spie on 25 Apr 2023 Terms of Use: https://www.spiedigitallibrary.org/terms-of-use 